\title{
Climate Change: Its Consequences And India's Response
}

\section{S C Gupta}

\author{
Department of Law, HN B Garhwal University Campus, Pauri Garhwal- 246001 \\ *Corresponding Author Email: scgupta@gmail.com
}

Received: 2.9.2019.; Revised: 11.11.2019; Accepted: 20.12.2019

OSociety for Himalayan Action Research and Development

\begin{abstract}
Climate Change has become quite the 'game - changer' today which is forcing human beings to explore new ways (scientific, political, social \& legal) to address the phenomenon of climate change as well as the consequences arising from it. One such consequence is displacement due to climate change.
\end{abstract}

Keywords: Climate Change, Consequences, India, response

\section{Introduction}

In 1992, the United Nations Framework Convention on Climate Change was adopted. It has been ratified by 197 States. In the year 2015, the Paris Agreement was adopted.

It has been 13 years since the Nobel Peace Prize was awarded to IPCC (Intergovernmental Panel on Climate Change) and $\mathrm{Al}$ Gore ${ }^{1}$ for their efforts on Climate Change. In giving away the prize, the Committee made the observations 'The Norwegian Nobel Committee has decided that the Nobel Peace Prize for 2007 is to be shared, in two equal parts, between the Intergovernmental Panel on Climate Change (IPCC) and Albert Arnold (AL) Gore Jr. for their efforts to build up and disseminate greater knowledge about man made climate change, and to lay the foundations for the measures that are needed to counteract such change. Extensive climate changes may alter and threaten the living conditions of much of mankind. They may induce large-scale migration and lead to greater competition for the earth's resources. Such changes will place particularly heavy burdens on the world's most vulnerable countries'

It is a scientifically established fact now that the current climate change is being caused due to anthropogenic global warming. Climate Change is defined by IPCC as: A change in the state of the climate that can be identified (e.g.by using statistical tests) by changes in the mean and/or the variability of its properties and that persists for an extended period, typically decades or longer. ${ }^{3}$

It describes changes in the state of the atmosphere over time scales ranging from decades to millions of years. These changes can be caused by processes inside the earth, forces from outside (e.g., variations in sunlight intensity) or, more recently, human activities. Ice ages are prominent examples.

Climate change is any significant long-term change in the expected patterns of average weather of a region (or the whole Earth) over a significant period of time. Climate change is about abnormal variations to the climate, and the effects of these variations on other parts of the Earth. Examples include the melting of ice caps at the South Pole and North Pole. These changes may take tens, hundreds or perhaps millions of years. In recent usage, especially in the context of environmental policy, climate change usually refers to changes in modern climate.

'Prevention is better than cure'. The saying is also self- explanatory. Mitigation and adaptation are basically two broad approaches to act on climate change. Mitigation can be understood to be more of a 'preventive' approach whereas adaptation can be understood to be more of a 'curative approach'. IPCC, 
the pioneer in terms of collating evidence - based research on climate change, has defined mitigation and adaptation. Mitigation refers to interventions that seek to reduce the emission of the greenhouse gases or remove them through sinks. ${ }^{4}$ Adaptation is a process of adjustment to actual or expected climate and its effects, which can ameliorate or avoid harm or exploit beneficial opportunities. ${ }^{5}$

However, IPCC (2014) has stated in its Climate Synthesis Report, "Many adaptation and Mitigation options can help address climate change, but no single option is sufficient by itself. Effective implementation depends on policies and cooperation at all scales and can be enhanced through integrated responses that link mitigation and adaptation with other societal objectives. " 6

India ratified the Kyoto Protocol on 26 August 2002. In 2006, India formulated the National Environment Policy- 2006, which outlines essential elements of India's response to climate change. These, inter alia, include adherence to the principle of common but differentiated responsibility and respective capabilities of different countries, identification of key vulnerabilities of India to climate change, in particular impacts on water resources, forests, coastal areas, agriculture and health, assessment of the need for adaptation to climate change and encouragement to the Indian industry to participate in the Clean Development Mechanism (CDM) ${ }^{7}$

The then Prime Minister, Dr. Manmohan Singh, set up a high level advisory group called the Prime Minister's Council on Climate Change, on climate change issues which includes on

Government representatives and non-government members. The Council coordinates National

Action Plans for assessment, adaptation and mitigation of climate change. It also advises the government on proactive measures that can be taken by India to deal with the challenge of climate change. It will also facilitate inter-ministerial coordination and guide in formulating policies in relevant areas. ${ }^{8}$

On 30 June 2008, the Prime Minister released India's National Action Plan on Climate Change (NAPCC). The NAPCC then sets out eight "National Missions" as the way forward in implementing the government's strategy and achieving the National Action Plan's objectives. ${ }^{9}$

The missions are:

1. National Solar Mission.

2. National Mission for Enhanced Energy Efficiency.

3. National Mission on Sustainable Habitat.

4. National water Mission.

5. National Mission for Sustaining the Himalayan Ecosystem.

6. National Mission for a Green India.

7. National Mission for Sustainable Agriculture.

8. National Mission on Strategic Knowledge for Climate Change.

To enhance knowledge about the impacts of climate change at the national and sub-national

level, Indian Network for Climate Change Assessment (INCCA) was launched on 14 October 2009. ${ }^{10}$

The Government of India created the National Clean Energy Fund (NCEF) n 2010 for the purpose of financing and promoting clean energy initiatives and funding research in the area of clean energy in the country. ${ }^{11}$

On 10 July, the Honorable Finance Minister of India announced an allocation of Rs. 100 crore towards a newly established National Adaptation Fund. This fund will assist national and State level activities to 
meet the cost of adaptation measures in area that are particularly vulnerable to the adverse effects of climate change. ${ }^{12}$

Recently, the term 'Climate Change' has been added to Ministry of environment and Forest by the new government. The decision of the present Prime Minister Mr. Narendra Modi for changing the nomenclature of the Ministry to 'Ministry of Environment, Forest \& Climate Change' is highly thoughtful and visionary. It takes into account the contemporary trends related to issues pertaining to climate change. ${ }^{13}$

\section{References}

1. AL Gore acted as the Vice President of the United States under President Bill Clinton from 20 January 1993 to 20 January 2001. Rinkesh, 'AL Gore and his views on Global Warming' (Conserve Energy Future)www.conserve-energy-future.com/al-gore-and-and-global-warming.php

2. 'The Noble Peace Prize for 2007'( The Noble Prize Organization, 12 October 2007www.nobelprize.org/prizes/peace/2007/press-release/

3. J.B.Robin Mathews (ed.), 'Glossary' (IPCC $\quad$ SR1.5 2018www.ipcc.ch/site/assets/uploads/2018/11.sr15_glossary.pdf

4. Mach, K.J.,S.Planton, and C. von Stechow (eds.), 'IPCC,2014: Annex II: Glossary' (2014) IPCC 118.

5. ibid 125

6. 'Topic 4: Adaptation and Mitigation' (IPCC, 2014), https://ar5-syr.ipcc.ch/topic_adaptation.php.

7. Proceedings, International Conference on Mitigation of Climate Change: Law, Policy and Governance 25-27 April 2014, available at http://clc.du.ac.in/gallary/proceedings\%20full\%20book.compressed.pdf accessed

8. Ibid

9. "8 Mission Launched as Part of NAPCC", Press Information Bureau (Government of India), available at http://pib.nic.in/newsite/erelease.aspx?relid=58313

10. "India's Progress in Combating Climate Change", Ministry of environment, Forest \& Climate Change, available at http://www.moef.nic.in/sites/default/files/pressrelease/Indian_Country_Paper_Low_Res.pdf>

11. Ibid.

12. "India's Progress in Combating Climate Change", Ministry of environment, Forest \& Climate Change, available at http://www.moef.nic.in/sites/default/files/pressrelease/Indian_Country_Paper_Low_Res.pdf

13. Ministry of Environment and Forests undergoes a nomenclature change; government serious to tackle climate change, The Economic Times (May 28, 2015), available at http://articles.economictimes.indiatimes.com/2014-05-28/news/50149634_I_climate-change-navrozdubash-climate-action-network. 